\title{
Adaptation of economy attitude scale to Turkish culture: Validity and reliability study
}

\author{
Bulent ALAGOZ \\ Gaziantep University, Faculty of Nizip Education, Turkey. \\ Received 14 September, 2014; Accepted 4 December, 2014
}

\begin{abstract}
Economics affects us no matter what role we play in social life. Its foundation as a science was laid by the studies of Adam Smith, and since history it has become one of the disciplines accepted in university curriculums. Scarcity, opportunity costs and abandoning something in order to obtain another one are the core concepts of this discipline. These three concepts represent the heart of Economics and generally defined as "distribution of scarce sources". The purpose of this study is to examine the psychometric features of the discipline; the Economy Attitudes Scale is composed of two dimensions and 28 items measuring the attitudes towards economy subject of the students developed by 1979 United States Economy Education Joint Counsel. Totally, 500 Social Studies teacher candidates from Kilis, Adıyaman, Niğde and Gaziantep University participated in the program. After the translation processes, experts' opinion was taken for validity of language. Exploratory and confirmatory factor analysis studies were made for construct validity. The results of exploratory factor analysis revealed that the scale explained $56.936 \%$ of the two dimensions. The model adaptation of twodimensional structure was tested via confirmatory factor analysis and the adaptation index is at good level (RMSEA=.081, GFI=.96, CFI=.98, AGFI=.96, NFI=.95, NNFI= .97, SRMR=.70). These sub-dimensions are the attitude towards economy course and complex economy attitudes. In conclusion of the reliability analysis of the scale, internal consistency coefficient was found as .87 . The findings support that the scale shows a sufficient internal consistency and teacher candidates carry a sufficient validity in measuring the attitudes towards economics course.
\end{abstract}

Key words: Economy attitudes scale, economy education, economics education, validity and reliability.

\section{INTRODUCTION}

Calvin Coolidge says "economics is the preparations that we make today in order to meet developments in the future" (John Calvin Coolidge, Jr. 4 July 1872 - 5 January 1933. $29^{\text {th }}$ Vice President and $30^{\text {th }}$ President of United States). What kind of preparation is mentioned here? It is not wrong to make preparations for developments, with the potential to penetrate all fields of life; they affect and will affect all people without exception. According to Schug and Walstad (1991), economics affects us no matter what roles we play in social life (worker, civil servants, shopkeepers, consumer, producer, citizens). What does this preparation contain and how should the education discipline known as Economics?

The foundations of Economics were laid by the studies

E-mail: balagoz@gantep.edu.tr. Tel: 90+506 7153831.

Authors agree that this artic le rema in pemanently open access under the terms of the $\underline{C}$ reative Commons Attribution License 4.0 Intemational License 
of Adam Smith (especially Wealth of Nations, 1776). From history till date, Economics has been one of the disciplines available and accepted in university curriculum (Hodkingson and Perera, 1996). Scarcity, opportunity costs and abandoning something to obtain another thing are the core concepts of this discipline. These three concepts represent the hearth of the course and generally described as "distribution of scarce resources” (Mergendoller et.al., 2000).

Social sciences education researchers addressed widely what economics and economcs education are and what the concepts are composed of. Limited resources, limitless requests and production, consumption, distribution and exchange movements are the important headings of economy and economics. For example, according to Martorella et al. (2005), economy is related to production, consumption and exchange. Michaelis (1988) also expressed that economic system is a way of production and usage of the people in a country. Parker (2001) expressed that economy is a work about production, distribution, exchange and consumption of the goods and services of which people are in need in scarcity conditions. While Naylor and Diem (1987) are drawing attention to the fact that all societies have to overcome scarcity problem, Garcia and Michaelis (2001) defend that being shared of the countries' sources by the people equally is a serious economic problem. Singer (2003) expressed economics as a controversial topic besides mentioning the production and distribution of goods. According to him, economy examines how the people produce and distribute the goods they need in order to remain alive. Turner (1999) points out that there is a connection between economics literature and the instruments of capitalist economy system. The mentioned instruments are listed as follows: the effect of technology on the society; global commerce and economic cohesion; environmental effect on economic decisions; the role of governments in managing modern economies; the relationships between private companies and their employees; the distribution and usage of limited sources and individual investment strategies; money and exchange, credit, banking transactions, budget and making economic plan.

Economics aims to provide economy insight and problem solving skills required for solving both social and economic problems (Walstad, 1979). Siegfried and Fels (1979) noted that one of the purposes of economics is to make the students have extensive knowledge about political issues and to increase the sensitivity towards political, economic and social system. Schug and Walstad (1991) said the purpose of economics is to teach the logic of economy and to help practice it. If the students are taught the logic of economics, they will be able to analyze economic events in more explicit way.

The conditions affecting the success of students in economics negatively/positively have occupied and are occupying the agenda of the educators.
Mann and Fusfeld (1970) emphasize that effective educator incites the students to examine beliefs, emphasize value problems about economic topics and transform them into active discussion environment. Siegfried (1979), Siegfried and Fels (1979), Charkins et al. (1985), Becker (1997) and Kennedy and Siegfried (1997) emphasize the quality of education and the connection between teaching-learning methods and highlight that different students learn the most suitable teaching strategy related to teaching economics in all license programs via traditional lecture method, which offers alternative learning methods. Benzing and Christ (1997) express that $44 \%$ of the academicians who participated in the research answered the question, "How do the students learn best?" as "if they participate in the course and extracurricular activities". Armento et al. (1996) mention the necessity of the interdisciplinary economy education and being treated in a logical way and discovered from different ideological viewpoints.

Again according to Armento et al. (1996), economic subjects are complex and embedded into social, political and historical contexts of life. The subjects must be thought and studied in the ways reflecting this richness. The role of social sciences class is to support the students to think logically about important economic matters rather than being hasty and dogmatic and inciting them to being thoughtful and aware of the inquiry and appreciation. Wyk (2012) suggests that the way of being successful by students of economics is to develop innovative teaching applications that will make the classroom more entertaining and attractive and to integrate the data from real world, simulated economy games, cartoons with the subject of economy, quizzes about economy and case studies with teaching content.

\section{Purpose}

Economy that is effective in all decisions makes our lives and determines every kind of role that we play in daily life. But, there is no link between the disciplines in social sciences and being located in social sciences teaching license program as more than one (Economy, General Human and Economic Geography, Turkey Human and Economic Geography); and there is no measurement tool adapted and developed to be used by social sciences educators in local literature. This is the main reason for conducting this study.

As it is said by a young banker in an interview on television, "the purpose of the market is not to solve social problems". When we put growth instead of development, market instead of planning, the subject and purpose of the economy change; while the welfare of people/society is being regarded as a problem, the speculations made over monetary magnitudes and stocks gain value (Müfit, 2010). To what degree do lecturers who access economy over only monetary values and 
certain terms and who are trained in economics-business teach economy lesson to social sciences teacher candidates and what kind of acquisitions do the students have in the lesson remain a serious gap in local literature. Another purpose of this study is to take the first step in order to fill this gap and bring measurement tool that social scientists who are interested in the subject can benefit in Turkey.

\section{METHOD AND MATERIAL}

\section{Sample}

The adaptation study of Economy Attitude Measure to Turkish was done in fall semester in 2012-2013 education years. While making adaptations, seven (7) different sample groups were used, and psychological measurement tool adaptation process composed of seven (7) steps of Deniz (2007) was used. First of all, it was accepted that scale development study will be more difficult than adaptation study in terms of usability. The second step is the process of permission and it was given permission from Prof. William Walstad (Ph.D) playing an important role in development study of the scale by explaining that it is aimed at making an educational study via e-mail (wwalstad1@unl.edu) on 7/8/2013. The scale was developed by The Joint Council on Economic Education-JCEE in 1979. Prof. Walstad was both inside the study as Project Manager of Working Group to perform the development study and one of the two authors of the study narrating how the scale is developed (Soper and Walstad, 1983). Therefore, Prof. Walstad was chosen to give permission due to these reasons.

The third step includes translator choice that each item is researched in terms of English-Turkish coherence under the scope of language validity study of Economy Attitude Scale. In order to do this, five (5) volunteer lecturers were identified as translators who speak both languages fluently, familiar with the cultures studied (English and Turkish), knowledgeable about the scaled structure. All of the translators have doctorate degree in the fields of English teaching and English Language and Literature.

The forth step is the translation process. The application about translation is conducted as translation from the source language (English) to target language (Turkish) and then to source language again. In advanced translation performed from the source language to the target language, the translators mentioned the $3^{\text {rd }}$ item chosen. The five (5) lecturers conducted the translation from the source language to target language (advanced translation) independent of each other (Harkness, 2010). Following this process, Economy Attitude Scale Translation Validity Suitability Degree Form whose English original items were written on the left and Turkish translations were written on the right was formed. With the help of this form, six (6) English language specialists formed by instructors and lecturers were asked to read the original items of the scale carefully at first; then their translation and the extent their translation meets the original item in terms of meaning and content (if it meets completely, it is 10; if it is not, the range of 0 is used). Taking the suggestions of the experts into account, the necessary changes in Turkish translation were made. Turkish form item number saves its order in the original form in terms of all points like item order. In the next process, 5 (five) lecturers having doctorate degree in the fields of Turkish Teaching and Turkish language and Literature scaled the suitability and intelligibility levels of each items in Turkish form for Turkish grammar in terms of Turkish language rules by using Economy Attitude Scale Language and Meaning Validity Suitability Degree Form (if each item corresponds to Turkish completely in terms of grammar and understandability, the range of 10 is used; if it does not correspond it, the range of 0 is used.). By taking into account the opinions of the experts, the necessary changes are made in Turkish translation and the last shape is given to the Turkish form of the scale. And then, a researcher and a translation expert examined both the translation texts and agreed that the texts expressed the original scale items of the texts enough. Following the advanced translation, the back translation made from target language to source language was conducted by two expert lecturers independent of each other. It has been detected that the four translation texts obtained are consistent in terms of meaning and concept.

The fifth step is to review and detect the linguistic equality. The adapted form of the scale has been revised and when four translation texts were evaluated together, it was seen that Turkish text meets the original expressions in English text enough in terms of meaning. And then it was passed to the linguistic equality studies of the scale between English and Turkish versions. In this process, totally 50 (22 of which are third and 28 of which are forth class) students receiving education in Gaziantep University Faculty of Sciences of the Department of Western Languages and Literature Department of English Language and Literature applied the English and then Turkish forms of the scale in two weeks. The results obtained from both applications have shown that the difference in all of the items in terms of test-retest responses is not statistically significant.

It was passed to content validity study of the scale. For this, 10 volunteer lecturers having one of the features that (i) working as a lecturer in the departments of education in universities and (ii) being graduated from doctorate degree in the field of education have expressed their opinion. 2 of the lecturers work in guidance and counseling, 2 of them in education administration and supervision, 2 of them in education programs and training and 2 of them in the department of measurement and evaluation in education.

The sixth step is pilot implementation process. In this process, 54 second-grade students receiving education in Gaziantep University Faculty of Education Department of Elementary Social Studies Teacher Education program, Turkish form that had been detected to be consistent in terms of meaning and concepts were applied every two weeks. The results obtained from both applications indicated that all of the items except for the difference in the responses of test-retest answers to $16^{\text {th }}$ and $17^{\text {th }}$ items were not statistically significant. In the item analysis transition made afterwards, this situation was not taken into consideration. In conclusion of this application, it was verified that the scale provided appearance and language validity (Küçükahmet, 2005).

In conclusion of the language validity study of Economy Attitude Scale, the theoretical universe of this study is Turkish teachers since it is planned to be applied on Turkish teachers. But the workable universe of the study includes teacher candidates continuing to two Education Faculties. Totally 406 classes of social sciences teacher candidates, 200 of which is male and 206 of which is female and whose ages range from 19 to 23 continuing the lessons in the Faculty of Education in Kilis and Adıyaman Universities in 2012-2013 education years and who were chosen deliberately as sample participated in the study voluntarily for validity and reliability analysis. Following that the missing or incorrect answers are omitted from the study, statistical analysis was made on 400 teacher candidates. In the literature, in the choice of sample size, it is seen that different researchers have different suggestions. It was stated that the sample size can be identified according to Büyüköztürk (2007) $n / k>2$ formula. Here, $n$ represents participants, $k$ represents the item number in the scale and it is recommended that the result to be obtained must be greater than 2 . When the formula is applied to this study, 406/28= 11.22 and $14.5>2$ are obtained. Şencan (2005) defends that the sample volume must be as big as being five events for each sample. Considering that the total variable (item) number in the scale is 44 , it is reached to the conclusion of $28^{\star} 5=140$ and in this case, it is understood that 406 participants are enough. Bademci (2011) expresses that the sample size must be formed by at least 
400 people for reliability and validity estimates or studies. Guadognali and Velicer (1988), Altunışık et al. (2005), Büyüköztürk et al. (2008), Kalaycı (2008), Kuş (2009) and Arsalani et al. (2011) left the identification of sample size to the researchers. Following the completion of seventh and the last step, it was passed to be transferred of the interpretations with the results of statistical transitions for the identification of validity and reliability of the study.

\section{Data collection tools}

In this study, the data and Economy Attitude Scale (JCEE, 1979) were collected via Economy Attitude Scale Translation Validation Compliance Rating and Economy Attitude Scale Language and Meaning Validation forms prepared and applied by the researcher.

Economy Attitude Scale (EAS): In 1979, with the increase in the pressures on economy education the Joint Council on Economic Education-JCEE has been charged with developing a measurement tool formed by two divisions and measuring the attitudes and sensorial domain of the students and made suitable for the country. The commission developed Economy Attitude Scale formed by 28 items (Survey on Economic Attitudes-SEA). There are two subdimensions of the scale. The first dimension of EAS intensifies on the attitudes of economy as a discipline or course (Attitudes toward Economics-ATE). The second sub-dimension aims to measure the quality of joint economy attitudes of the students (Economic Attitude Sophistication-ECAS). Each part of EAS consists of 14 items and the scale is in the type of 5 point Likert (Soper and Walstad, 1983).

The first steps in the scale development process, project manager to carry out the study and to select the Working Committee. In addition, a National Advisory Committee was charged to evaluate the decisions of this committee. Working Committee decided to have two separate divisions. One of them would measure ATE and the other one would measure ECAS. As a working domain ATE would intensify the answers of the individuals related to the economy and would measure the effect of the answers to the discipline. A member of Working Committee has just completed the development process of an ATE scale and adaptation process to the country. Following the last version of ATE, Working Committee decided that this measurement tool would be extremely suitable for evaluating the attitudes related to the discipline with these slight changes. About the second part of EAS, Working Committee examined the big part of current measurement tools again. This investigation included all of the researches. However, in this situation, it cannot access a satisfactory tool completely. It has been understood that some tools have reading level problems and another part of it has measurement qualities that can be questioned. As an example to the last problem, the measurement tools developed in order to measure liberal or protective attitudes is understood to have questionable validity towards the problem of identifying whether it represents "liberal" or "protective" viewpoint attitude expression (Soper and Walstad, 1983).

Economy Attitude Scale with two parts began to be applied nationally in May 1979. In 67 high schools chosen from all the geographical regions of the country, the application was carried out. Purdue University Measurement Research Center (MRC) identified the sample and tests and demographic data was collected under the scope of cooperation with Joint Council. In conclusion of the measurements, the internal consistency coefficient of the Attitudes towards Economy (ATE) was found high (Cronbach's alpha $=.88$ ). The internal consistency coefficient of Complex economic attitudes (ECAS) was found on the lower level (Cronbach's alpha $=.66$ ). When this finding is compared to ATE in terms of ECAS, this was not an expected situation because it was evaluating the variable opinions about various economy subjects and short term measurement transitions. Nevertheless, the whole of the item correlation of the scale is statistically significant (0.01) and the estimated reliability is good compared to many affective measurements (Soper and Walstad, 1983; Phipps and Clark, 1993).

In 1980, the reliability studies were conducted as pretest-posttest in Missouri-St. Louis and Northern Illinois Universities and from the data obtained from the groups participated in the study Cronbach alpha value was found to be high. Therefore, it was understood that the reliability and internal consistency coefficient of EYT and ECAS scales were at desired level (Soper and Walstad, 1983).

The first reliability calculation of ECAS was conducted on a small group consisting of 13 economists and so it was aimed to reveal the failures in the development process. In order to test the content validity of ECAS, a scale consisting of 20 items (231 people) was sent to all the administrators of Joint Council and Central Administrators. While 14 of the 20 items were the ones randomly chosen from ECAS items, and the remaining 6 items were the ones that were previously rejected by the economy specialists. The administrators were asked for stating whether they agreed with the scale items or they evaluated the answering as unacceptable. Unanswered scales were sent back in an envelope and together with the additional information (Soper were Walstad, 1983).

While making consensus on the 14 items, it could not be made consensus on 6 items previously rejected. 149 of the 231 administrators $(64.5 \%)$ returned. As expected, it was achieved consensus on 14 items and related to these 14 items, the answers as $I$ agree or $I$ do not agree at the rate ranges from 70.3 to $99.3 \%$. The mean is $85.8 \%$. It was answered to 6 "confounding" items at the changing rate from 25.2 to $67.8 \%$. In Pearson correlation coefficient calculation conducted to measure the distinctiveness of two sub dimensions, of the measurements for both sub-dimensions in only one of the measurement (76 people from Missouri-St. Louis University and 110 people from Northern Illinois University for 4 times each) significant difference at the level of 0.05 was found and was concluded that ATE and ECAS were enough for measuring different things (Soper and Walstad, 1983).

Being more positive of the Attitudes towards Economy (ATE) may be a desired conclusion for economy lesson. However, taking an undesired result from the whole class should not be evaluated as "bad" or "wrong". ATE only submits classroom sensitivity index that may have beneficial information related to economy for the teachers and the researchers. Similarly, complex economy attitude (ECAS) is neither the measurement of "true" opinions list nor it has been designed for compelling the students to adapt to the consensus of the economists related to economy. ECAS simply evaluates how well the students adopt the opinions related to the current status of the information or to what extent they are inclined to adopt these opinions. High ECAS note may not be an explicit result of a course or program and even it should not be. Moreover, there is a serious danger: Economy Attitude Scale (EAS) users may feel they have to take a glance to numerical values before and after (Soper and Walstad, 1983).

Another statistical study related to Economy Attitude Scale was conducted by Phipps and Clark (1993). The authors used two different data sets for this application. For the analysis, two data sets were used. The first data was obtained from national adaptation sample of Economy Literacy Test (Test of Economic Literacy-TEL; Soper and Walstad, 1987). The mentioned data was collected in winter and spring semester. They were the same with the data produced from the sample paired for their own analysis by Walstad and Soper (1989) and consisting of 1630 participants and pretestposttest applications of which were conducted. The original data was paired for all of the answers to EAS pretest-posttest, and it was benefited from the data obtained from a sample consisting of 1507 participants. The second data set obtained from the study of Clark and Hingsmith (1991) was formed by the extensive data consisting of the answers given by 995 high school students taking economy lesson in 1990-1991 academic years. 814 of 995 students completed the test and factor analysis was made over these answers. All the students in the sample have taken the economy lesson in 
which the extensive curriculum materials produced by National Economy Education Council were used. At the same time, factor analysis was applied to extensive data in order to test healthy findings of EOT data analysis (Phipps and Clark, 1993).

Factor analysis was made separately both for all of the 28 items of Economy Attitudes Scale (EAS) and The Attitudes towards the Economy (ATE) and Complex Economy Attitudes (CEA) that are subscales. The sample sufficiency coefficient of KMO and Cronbach's alpha internal consistency coefficient were calculated for each subscale separately (Table 1 See Appendix). The results of facto analysis verify the assumption of Soper and Walstad (1983): ETE and CEA are separate dimensions (Phipps and Clark, 1993).

\section{The analysis of the data}

All the statistical transitions of the study were conducted through SPSS 16.0. While evaluating the study data, descriptive statistical methods (Mean, Standard Deviation) were used.

\section{FINDINGS}

\section{I-Study Group-Study}

The linguistic equivalence of EAS and test-retest application performed for linguistic and appearance validity studies were conducted on two separate groups $(n=50$ and $n=54$ ) (Table 2 and 3 See Appendix).

According to the tables, the difference in terms of testretest answers in all questions are not statistically significant $(p>0,05)$. In Table 3 , the results of the application verifying that the scale ensures language and appearance validity are given.

According to the table, the first test mean $(x=2,000)$ of the question that is $16^{\text {th }}$ item as "the health services must be free for all the citizens" was found higher than retest mean $(x=1,780)(t=2,124 ; p=0,038<0,05)$. The first test mean of the question that is $17^{\text {th }}$ item as "The Banks Should not Compel the Consumers to Pay Interest for the Credits" $(x=1,590)$ was found lower than retest mean $(x=1,890)(t=-3,287 ; p=0,002<0,05)$. In other questions, the difference in terms of test-retest answers are not statistically significant $(p>0,05) .16^{\text {th }}$ and $17^{\text {th }}$ items having statistically significant difference have been taken into account in validity and reliability studies.

Cronbach's alpha value was calculated for internal consistency test of EAS.

Study group consists of the students from the Department of Social Sciences Teaching in Kilis and Adıyaman Universities. Under this scope, 406 social sciences teacher candidates were assigned as the participants of the study and when incorrect and blank papers were excluded, the descriptive factor analysis was conducted over 400 pieces of data.

\section{II- Cronbach's alpha value was calculated for internal consistency test of EAS-Study Group-Transition- Study}

In internal consistency test conducted over 28 items with
400 teacher candidates Cronbach's alpha value was found to be .63 . So, $4,5,9,15,16,20,23$ and $28^{\text {th }}$ items with low factor load were omitted from the scale. In Crobach's alpha test conducted again with remaining 20 items, following the internal consistency coefficient value that was found to be .84 the items of $13,14,18$ and 19 with low factor level were omitted from the scale and the test was repeated for the third time. Cronbach's alpha value of test result conducted over 16 items was calculated as .86. The items of 2 and 12 were omitted from the scale at this level since their factor load is low and the same test was repeated with 14 items for the fourth time and extremely high value as .873 was found (Peterson, 1994; Şencan, 2005). So, with the scale form consisting of 14 items whose internal consistency coefficient was high, it was passed to descriptive and confirmatory factor analysis tests.

In order to detect the construct validity of Economy Attitude Scale, descriptive factor analysis was conducted.

The descriptive factor analysis results conducted in order to detect the construct validity of EAS was conducted with 400 social sciences teacher candidates in Kilis and Adıyaman University Faculty of Education.

\section{III-Study Group-Transition}

In order to reveal the construct validity of the scale, descriptive and confirmatory factor analysis method was conducted on the samples different from each other. In conclusion of Barlett test conducted $(p=0.000<0.05)$, it was detected that there was a relationship between the variables taken to factor analysis (Altunışık et al., 2005). In conclusion of the test conducted $(\mathrm{KMO}=0.874>0.60)$, it was detected that sample size was enough for factor analysis application (Ekici, 2009). According to Kaiser (1974), .70 or a higher KMO coefficient is enough for conducting factor analysis and.80 or a higher value is excellent. In factor analysis application, varimax method was chosen; the structure of the relationship between the factors remained the same. In conclusion of the factor analysis, the variables were gathered under 2 factors whose total explained variance was $56.936 \%$. Scree plot test also verifies this. That Economy Attitude Scale is a valid and reliable tool according to alpha found related to the reliability and to variance value explained was understood. Factor structure belonging to the scale is seen in Table 4 and Figure 1 See Appendix.

In factor analysis evaluation of Economy Attitude Scale, being taken of the factors with eigenvalues greater than one, being high of the factor loadings indicating the weight of variables within the factor, being not closed to each other of the factor loadings for the same variable were taken into account. The reliability coefficient of the factors forming the scale and being high of the explained variance rates indicates that the scale has a strong factor structure. The items in the first factor were taken as Attitude towards Economy Course. The reliability of 7 
items forming this factor was identified as alpha $=0.873$ and explained variance value was as $28.621 \%$. The items in the second factor were taken as Complex Economy Attitudes. The reliability of 7 items forming this factor was identified as alpha $=0.861$ and explained variance value was $28.315 \%$. While calculating the points of the factors in the scale, after the values of the items in the factor were summoned, they were divided into item number (arithmetic mean) and factor points were obtained.

Confirmatory factor analysis (CFA) test applied to detect the construct validity of Economy Attitude Scale was conducted with 100 social sciences teacher candidates studying in Niğde University Faculty of Education. CFA test of EAS was applied on a different sample because the most common problem in the structural analysis of the items designed for measuring personality features, attitudes, psychotherapy or the other clinical findings is the inclination of being rejected were tested by using CFA model when the structures obtained through Descriptive Factor Analysis (DFA) were tested statistically. The typical scenario of a well-planned research is like this: First, an understandable and replicable CFA model is one of the first studies. Then, a DFA model based on this CFA solution and the results showing that the model does not fit in well are tested in a new sample. Nevertheless, the adaptation may be bad when it is made DFA compatible with the same sample that CFA offers a good solution (Ferrando and Lorenzo, 2000). Considering the risk that Ferrando and Lorenzo draw the attention CFA model was analyzed over a different sample via DFA together with the results showing that the model is compatible and the obtained results are given as follows.

\section{Transition}

The findings related to the validity studies of Economy Attitude Scale were tested on a different sample with DFA; the model belonging to two-factor structure consisting of 14 items on the theoretical basis. In DFA executed over 14 items, positive factor loading in all the items was provided. So, the adaptation indexes obtained in conclusion of DFA applied in order to be tested of 14 items and two latent variables [Goodness of Fit Index = GFI), were adjusted, Adjusted Goodness of Fit Index $=\mathrm{AGFI}$, Comparative Fit Index $=\mathrm{CFI}$, Normed Fit Index $=\mathrm{NFI}$, Non-normed Fit Index $=\mathrm{NNFI}$, Standardized Root Mean Square Residual=S-RMR to Root-MeanSquare Error of Approximation=RMSEA] were examined and Chi-square value was found to be $(x 2=265,15$, $\mathrm{N}=400, \mathrm{sd}=73, \mathrm{x} 2 / \mathrm{df}=3,6, \mathrm{p}=0,000$ ) significant. Fit Index Values were found at high levels: RMSEA $=0,081$, $\mathrm{GFI}=0,96, \mathrm{CFI}=0,98, \mathrm{AGFI}=0,96, \mathrm{NFI}=0,95, \mathrm{NNFI}=0,97$, SRMR=0,070 (Dickey, 1996; Stapleton, 1997; Byrne, 1998) (Figure 2 See Appendix).

The saturated model was obtained by using Modification Indexes for DFA, the items that " $1^{\text {st }}$ I like reading the articles related to Economy subjects" and " 8 th Economy is a loss of time" are extremely similar. It was seen that the items " $3^{\text {rd }}$ I like Economy course" and "I like $10^{\text {th }}$ Economy" are very similar. " $25^{\text {th }}$ Inflation resulted from greedy business/trade union leaders" and " $26^{\text {th }}$ The Businesses have too much benefit" are the questions that are theoretically to each other (Figure 3 See Appendix).

According to DFA result, it was observed that the item factor loadings ranges from 0,49 to 0,91 and $R^{2}$ values ranges from 0.24 to 0.83 (Table 5 See Appendix).

\section{DISCUSSION}

Economics is seen in social sciences teaching license program as a course under more than one course topics; however it creates a serious gap in local literature related to what the teacher candidates' attitudes towards the lesson or what they think generally about economy. That the attitudes towards economy were examined seriously by economics specialists and educators is understood from the national literature. That the attitudes towards economics were examined in a serious way by economics specialists and educators is understood from international literature. The researches intensify on solving the mystery of non-cognitive behavior in economics. In the examination of human behavior, the researchers giving importance to the senses at least as much as cognition defends that only this reason can better the rightness of these anxieties related to the subject. As we are witnessed in our daily life for several times, even if the individuals understand the results of the economy activities and policies, they may behave "unreasonable" in economic sense. Therefore, while the attitudes towards economy were examined, the senses as well as the cognitive domain affecting behaviors especially when the options have matters of public interest, they must not be ignored. Moving from this point, the aim of this study is to adapt Economy Attitude Scale developed to measure the attitudes towards economy course by Joint Council of Economy Education in 1979 on the sample consisting of 400 teacher candidates. The study was conducted in eight processes.

First of all, it was accepted that scale development studies would be more difficult than adaptation study in terms of usability, and then, it was taken permission from Prof. William Walstad (Ph.D.) who played an important role in scale development study. In the third step, five (5) volunteer lecturers were identified as translators who speak both languages fluently. The forth step is translation process. The application about translation is conducted as translation from the source language (English) to target language (Turkish) and then to source language again. Following this process, Economy Attitude Scale Translation Validity Suitability Degree Form and Economy Attitude Scale Language and Meaning Validity Suitability Degree Form were developed. 
Considering the suggestions of the specialists, the necessary changes were made in Turkish translation and the last form was given to the Turkish form of the scale. And then it was detected that four translation texts were consistent in terms of meaning and concept in conclusion of forward and backward translation processes.

In the fifth step, when the four translation texts were evaluated together, it was seen that Turkish text corresponds to the original expressions sufficiently in terms of meaning. And then the linguistic equivalence study between English-Turkish forms of the scale was conducted over English Literature students.

In the content validity study, 10 volunteer faculty members expressed positive opinions. In the sixth step, in conclusion of the application conducted with 54 teacher candidates, it was verified that the appearance and language validity of the scale were ensured. 400 social sciences teacher candidates participated in the study voluntarily for validity and reliability analysis.

In internal consistency test conducted for four times with 400 teacher candidates Cronbach's alpha value was found extremely high as .873. So, it was passed to descriptive and confirmatory factor analysis tests applied on different samples via a scale from with high internal consistency coefficient and consisting of 14 items.

Barlett test indicated the relationship between the variables taken to factor analysis and KMO test indicated that sample size was sufficient for factor analysis application. In factor analysis application, varimax method was chosen and the structures of the relationship between the factors were ensured to remain the same. In conclusion of factor analysis, the variables were gathered under two factors.

In DFA conducted over 14 items, positive factor loading was ensured in each factors. Fit index values were found to be RMSEA $=0,081, \mathrm{GFI}=0,96, \mathrm{CFI}=0,98, \mathrm{AGFI}=0,96$, $\mathrm{NFI}=0,95, \mathrm{NNFI}=0,97, \mathrm{SRMR}=0,070$.

By using Modification Indexes for DFA, saturated model was obtained. It is seen that the items of $1,8,3$ and 10 are very similar. 25 and $26^{\text {th }}$ items are seen to be the questions close to each other theoretically. According to DFA result, it is seen that item factor loadings range from 0,49 to 0,91 and $R^{2}$ value ranges from 0,24 to 0,83 .

As a conclusion, the Turkish form of Economy Attitude Scale can be evaluated as a scale having sufficient validity coefficient and validity indicators at acceptable level as its original. It is thought to be a beneficial tool that can be used in the researches to be conducted on Social Sciences and Class teacher candidates and performing the researches in which the scale will be used will ensure important contributions to the measuring power of this scale.

\section{Conflict of Interests}

The author has not declared any conflict of interests.

\section{REFERENCES}

Altunışık R, Coşkun R, Bayraktaroğlu S, Yıldırım E (2005). Sosyal Bilimlerde Araştırma Yöntemleri: SPSS Uygulamalı. Sakarya: Sakarya Kitabevi.

Armento BJ, Rushing FW, Cook WA (1996). An Approach to IssuesOriented Economic Education. In (Eds) R. W. Evans, D. W. Saxe. Handbook on Teaching Social Issues. (pp. 211-219). NCSS Bulletin 93. National Council for the Social Studies, Washington, D. C.

Arsalani N, Knoshknab MF, Ghaffari M, Josephson M, Lagerstrom M (2011). Adaptation of Questionnaire Measuring Conditions and Health Problems Among Iranian Nursing Personnel. Asian Nurs. Res. $5(3): 177-182$.

Bademci V (2011). Kuder-Richardson 20, Cronbach'ın Alfası, Hoyt'un Varyans Analizi, Genellenebilirlik Kuramı ve Ölçüm Güvenirliği Üzerine Bir Çalışma. Dicle Üniversitesi Ziya Gökalp Eğitim Fakültesi Dergisi 17:173-193.

Becker WE (1997). Teaching Economics to Undergraduates. J. Econ. Literature 35(3):1347-1373.

Benzing C, Christ P (1997): A Survey of Teaching Methods Among Economics Faculty, J. Econ. Educ. 28(2):182-188.

Büyüköztürk Ş (2007). Sosyal Bilimler için Veri Analizi El Kitabı. Ankara: Pegem Akademi Yayıncılık.

Büyüköztürk Ş, Çakmak EK, Akgün OE, Karadeniz Ş, Demirel F (2008) Bilimsel Araştırma Yöntemleri. Ankara: Pegem Akademi Yayıncılık.

Byrne BM (1998). Structural equation modeling with lisrel, prelis and simlis: Basic concepts, applications and programming. Mahwah, NJ: Lawrence Erlbaum Associates.

Charkins RJ, O'Toole DM, Wetzel JN (1985). Linking Teacher and Student Learning Styles with Student Achievement and Attitudes. J. Econ. Educ. 16(2):111-120.

Clark JE, Highsmith RJ (1991). Does Capstone improve learning in high school economics classes? Paper presented at the JointC ouncil on Economic Education/National Association of Economic Educators Annual Meeting, Louisville, KY, October.

Deniz ZK (2007). Psikolojik Ölçme Aracı Uyarlama. Ankara Üniversitesi Eğitim Bilimleri Fakültesi Dergisi, 40(1):1-16.

Dickey D (1996). Testing The Fit of Our Models of Psychological Dynamics Using Confirmatory Methods: An Introductory Primer. (Advances in Social Science Methodology 4 içinde. Editör: Bruce Thompson). London: JAI press Ltd.

Ekici G (2009). Biyoloji öz-Yeterlik Ölçeğinin Türkçe'ye Uyarlanması. Kastamonu Eğitim Dergisi 17(1):111-124.

Ferrando PJ, Lorenzo-Seva U (2000). Unrestricted versus restricted factor analysis of multidimensional test items: Some aspects of the problem and some suggestions. Psicológica 21(2):301-323.

Garcia J, Michaelis JU (2001). Social Studies for Children. A Guide to Basic Instruction. Allyn and Bacon.

Guadognali E, Velicer WF (1988). Relation of Sample Size to the Stability of Component Patterns. Psychol. Bull. 103(2):265-275.

Harkness JA (2010). Survey translation and the question of quality. In International Workshop on Comparative Survey Design and Implementation, Lausanne, Switzerland.

Hodkingson A, Perera N (1996). Why aren't they taking economics? Attitudes of first year students University of Wollongong. Case study. Department of Economics University of Wollongong. 34p.

Kaiser HF (1974). An index of factorial simplicity. Psychometrika, 39(1):31-36.

Kalaycı Ş (2008). SPSS Uygulamalı Çok Değişkenli İstatistik Teknikleri. Ankara: Asil Yayın Dağıtım.

Kennedy PE, Siegfried JJ (1997). Class size and achievement in introductory economics; Evidence from the TUCE III data. Econ. Educ. Rev. 16(4):385-394.

Kuş E (2009). Nicel-Nitel Araştırma Teknikleri. Sosyal Bilimlerde Araştırma Teknikleri Nicel mi? Nitel mi? Ankara: Anı Yayıncılık.

Küçükahmet L (2005). Öğretimde Planlama ve Değerlendirme. Ankara: Nobel Yayın Dağııım.

Mann WR, Fusfeld DR (1970). Attitude Sophistication and Effective Teaching in Economics. J. Econ. Educ. 1(2):111-129.

Martorella PH, Beal CM, Bolick CM (2005). Teaching Social Studies in Middle and Secondary Schools (4th ed.). Pearson Merrill Prentice Hall. 
Mergendoller JR, Maxwell NL, Bellisimo Y (2000). Comparing ProblemBased Learning and Traditional Instruction in High School Economics. J. Educ. Res. 93(6):374-382.

Michaelis JU (1988). Social Studies for Children. A Guide to Basic Instruction. (9th ed). Prentice Hall, Englewood Cliffs, New Jersey.

Müfit A (2010). Bu Bilgileri Gazetelerin Ekonomi Sayfasında Okuyamazsınız. Retrieved from http://www.odatv.com/n.php?n=bubilgileri-gazetelerin-ekonomi-sayfasinda-okuyamazsiniz--2109101200 at 01.07.2013.

Naylor DT, Diem R (1987). Elementary and Middle School Social Studies. New York: Random House.

Parker WC (2001). Social Studies in Elementary Education. Merrill Prentice Hall.

Peterson RA (1994). A Meta-Analysis of Cronbach's Coefficient Alpha. J. Consumer Res. 21(2):381-391.

Phipps BJ, Clark JE (1993). Attitudes toward Economics: Uni- or Multidimensional? J. Econ. Educ. 24(3):195-212.

Schug MC, Walstad WB (1991). Teaching and learning economics. In Shaver, J. P. (Ed.) Handbook of Research on Social StudiesTeaching and Learning. (pp.411-419)

Siegfried JJ (1979). Male-female differences in economic education a survey. J. Econ. Educ. 10(2):1-11.

Siegfried JJ, Fels R (1979). Research on Teaching College Economics: A Survey. J. Econ. Literature 17(3):923-969.

Singer AJ (2003). Social Studies for Secondary Schools: Teaching to Learn, Learning to Teach. Lawrance Erlbaum Associates.

Soper JC, Walstad WB (1983). On Measuring Economic Attitudes. J. Econ. Educ. 14(4):4-17.

Soper JC, Walstad WB (1987). Test of economic literacy: Examiner's manual. 2d ed. New York: Joint Council on Economic Education.

Şencan H (2005). Sosyal ve Davranışsal Ölçümlerde Güvenirlik ve Geçerlik. Ankara: Seçkin Yayıncılık.
Stapleton CD (1997). Basic concepts and procedures of confirmatory factor analysis. Educational Research Association, ReportsEvaluative (142), Speeches / Meeting Papers (150).

Turner TN (1999). Essentials of Elementary Social Studies. Allyn and Bacon.

Walstad WB (1979). Effectiveness of a USMES In-Service Economic Education Program for Elementary SchoolTeachers. J. Econ. Educ. 11(1):1-12.

Walstad WB, Soper JC (1982). A model of economics learning in the high schools. J. Econ. Educ. 13(Winter): 40-54.

Walstad WB, Soper JC (1989). What is high school economics? Factors contributing to student achievement and atti-tudes. J. Econ. Educ. 20:23-38.

Wyk van MM (2012). Measuring Students' Attitudes to Economics Education: A Factorial Analysis Approach. J. Soc. Sci. 31(1):27-42. 


\section{Appendix}

Table 1. Kaiser-Meyer-Olkin coefficients of sampling adequacy and cronbach's alpha (Phipps and Clark, 1993, 198).

\begin{tabular}{lcc}
\hline Data Set & KMO coefficient & Cronbah's alpha \\
\hline TEL & & \\
ATE pretest & .91 & .88 \\
ATE posttest & .90 & .86 \\
EAS pretest & .70 & .64 \\
EAS posttest & .71 & .68 \\
Capstone & & \\
ATE pretest & .91 & .87 \\
ATE posttest & .91 & .90 \\
EAS pretest & .69 & .60 \\
EAS postest & .73 & .68 \\
\hline
\end{tabular}

Table 1. English test-retest results $(n=50)$.

\begin{tabular}{|c|c|c|c|c|c|c|}
\hline & \multicolumn{2}{|c|}{ Test } & \multicolumn{2}{|c|}{ Retest } & \multirow{2}{*}{$\mathbf{t}$} & \multirow{2}{*}{$\mathbf{P}$} \\
\hline & Mean & SD & Mean & SD & & \\
\hline 1. I enjoy reading articles about economic topics. & 3,140 & 1,125 & 3,160 & 1,267 & $-0,227$ & 0,821 \\
\hline 2. Economics is dull. & 3,180 & 1,004 & 3,120 & 0,982 & 0,339 & 0,736 \\
\hline 3. I enjoy economics. & 3,160 & 1,095 & 3,060 & 1,132 & 0,711 & 0,481 \\
\hline 4. On occasion I read an unassigned book in economics. & 2,900 & 1,093 & 3,000 & 1,143 & $-0,430$ & 0,669 \\
\hline 5. I would be willing to attend a lecture by an economist. & 2,540 & 1,110 & 2,740 & 1,259 & $-0,849$ & 0,400 \\
\hline 6. Economics is one of my favorite subjects. & 3,640 & 1,083 & 3,620 & 1,193 & 0,134 & 0,894 \\
\hline 7. I use economic concepts to analyze situations. & 3,380 & 1,123 & 3,180 & 1,224 & 1,219 & 0,229 \\
\hline 8. Studying economics is a waste of time. & 3,540 & 1,147 & 3,560 & 1,181 & $-0,080$ & 0,937 \\
\hline 9. Economics is practical. & 2,800 & 0,990 & 2,680 & 1,058 & 0,573 & 0,569 \\
\hline 10. Economic ideas are dumb. & 3,460 & 1,092 & 3,340 & 1,042 & 0,579 & 0,565 \\
\hline 11. Economics is easy for me to understand. & 3,300 & 1,015 & 3,120 & 1,118 & 1,323 & 0,192 \\
\hline 12. Economics is a very difficult subject for me. & 2,840 & 1,095 & 2,900 & 1,147 & $-0,425$ & 0,673 \\
\hline 13. I hate economics. & 3,420 & 1,012 & 3,360 & 1,120 & 0,535 & 0,595 \\
\hline 14. Economics is one of my most dreaded subjects. & 3,160 & 1,037 & 3,220 & 1,016 & $-0,343$ & 0,733 \\
\hline 15. People should not have to pay taxes. & 3,140 & 1,309 & 3,260 & 1,175 & $-0,704$ & 0,485 \\
\hline 16. Free medical care should be provided for all citizens*. & 1,840 & 1,017 & 1,900 & 1,055 & $-0,363$ & 0,718 \\
\hline 17. Banks should not charge interest on loans to customers. & 2,020 & 0,915 & 2,200 & 1,143 & $-0,802$ & 0,426 \\
\hline 18. If everybody had more money, we'd all be better off. & 2,680 & 1,253 & 2,620 & 1,292 & 0,387 & 0,700 \\
\hline 19. Most people who don't have jobs are too lazy to work. & 3,300 & 1,165 & 3,040 & 1,355 & 1,391 & 0,171 \\
\hline 20. Most unemployed people are lazy. & 3,300 & 1,147 & 3,340 & 1,222 & $-0,292$ & 0,771 \\
\hline 21. Government should control the price of gasoline. & 1,920 & 0,986 & 2,160 & 0,912 & $-1,695$ & 0,096 \\
\hline 22. When a strike occurs, government should step in and settle the dispute. & 2,340 & 1,081 & 2,260 & 0,986 & 0,481 & 0,632 \\
\hline 23. Poeople should not be told how to spend their money. & 2,540 & 1,129 & 2,700 & 1,147 & $-0,850$ & 0,399 \\
\hline 24. Profits should not be regulated by government. & 2,860 & 1,143 & 2,920 & 1,027 & $-0,252$ & 0,802 \\
\hline 25. Inflation is caused by greedy business/union leaders. & 2,100 & 0,886 & 2,200 & 0,969 & $-0,626$ & 0,534 \\
\hline 26. Business makes too much profit. & 2,400 & 0,881 & 2,300 & 0,974 & 0,590 & 0,558 \\
\hline 27. When a business gets big, it should be controlled by government. & 2,580 & 1,126 & 2,640 & 1,191 & $-0,394$ & 0,695 \\
\hline 28. New factories are not needed. & 4,040 & 1,049 & 3,880 & 1,206 & 1,135 & 0,262 \\
\hline
\end{tabular}

*Word "Americans" was changed with word "citizens" for Turkish students. 
Table 3. Turkish test-retest results $(n=54)$.

\begin{tabular}{|c|c|c|c|c|c|c|}
\hline & \multicolumn{2}{|c|}{ Test } & \multicolumn{2}{|c|}{ Retest } & \multirow{2}{*}{$\mathbf{t}$} & \multirow[b]{2}{*}{$\mathbf{p}$} \\
\hline & Mean & SD & Mean & SD & & \\
\hline 1. I enjoy reading articles about economic topics. & 3,500 & 1,240 & 3,390 & 1,309 & 0,799 & 0,428 \\
\hline 2. Economics is dull. & 2,8101 & 1,245 & 2,890 & 1,093 & $-0,522$ & 0,604 \\
\hline 3. I enjoy economics. & 3,350 & 1,084 & 3,220 & 1,058 & 1,224 & 0,226 \\
\hline 4. On occasion I read an unassigned book in economics. & 2,590 & 1,141 & 3,040 & 1,331 & $-2,898$ & 0,005 \\
\hline 5. I would be willing to attend a lecture by an economist. & 1,930 & 1,286 & 2,200 & 1,323 & $-1,613$ & 0,113 \\
\hline 6. Economics is one of my favorite subjects. & 3,780 & 1,076 & 3,800 & 1,122 & $-0,142$ & 0,888 \\
\hline 7. I use economic concepts to analyze situations. & 3,150 & 1,156 & 3,240 & 1,063 & $-0,759$ & 0,451 \\
\hline 8. Studying economics is a waste of time. & 3,540 & 1,193 & 3,500 & 1,112 & 0,280 & 0,780 \\
\hline 9. Economics is practical. & 2,590 & 1,125 & 2,800 & 1,071 & $-1,667$ & 0,102 \\
\hline 10. Economic ideas are dumb. & 3,310 & 1,079 & 3,200 & 1,155 & 0,814 & 0,419 \\
\hline 11. Economics is easy for me to understand. & 3,260 & 1,049 & 3,310 & 0,987 & $-0,394$ & 0,695 \\
\hline 12. Economics is a very difficult subject for me. & 2,830 & 1,129 & 3,000 & 1,182 & $-0,894$ & 0,375 \\
\hline 13. I hate economics. & 3,200 & 1,234 & 3,260 & 1,136 & $-0,331$ & 0,742 \\
\hline 14. Economics is one of my most dreaded subjects. & 3,350 & 1,291 & 3,330 & 0,911 & 0,105 & 0,917 \\
\hline 15. People should not have to pay taxes. & 3,410 & 1,381 & 3,040 & 1,440 & 1,995 & 0,051 \\
\hline 16. Free medical care should be provided for all citizens*. & 2,000 & 1,099 & 1,780 & 0,984 & 2,124 & 0,038 \\
\hline 17. Banks should not charge interest on loans to customers. & 1,590 & 0,836 & 1,890 & 0,984 & $-3,287$ & 0,002 \\
\hline 18. If everybody had more money, we'd all be better off. & 2,980 & 1,325 & 2,930 & 1,242 & 0,293 & 0,771 \\
\hline 19. Most people who don't have jobs are too lazy to work. & 3,240 & 1,181 & 3,300 & 1,312 & $-0,375$ & 0,709 \\
\hline 20. Most unemployed people are lazy. & 3,410 & 1,125 & 3,570 & 1,238 & $-1,176$ & 0,245 \\
\hline 21. Government should control the price of gasoline. & 1,440 & 0,769 & 1,540 & 0,693 & $-1,093$ & 0,279 \\
\hline 22. When a strike occurs, government should step in and settle the dispute. & 1,690 & 0,748 & 1,610 & 0,529 & 0,753 & 0,455 \\
\hline 23. Poeople should not be told how to spend their money. & 2,700 & 1,298 & 2,650 & 1,246 & 0,282 & 0,779 \\
\hline 24. Profits should not be regulated by government. & 2,560 & 0,984 & 2,260 & 0,935 & 1,659 & 0,103 \\
\hline 25. Inflation is caused by greedy business/union leaders. & 2,870 & 1,318 & 2,410 & 1,125 & 2,305 & 0,025 \\
\hline 26. Business makes too much profit. & 2,280 & 0,811 & 2,350 & 0,781 & $-0,942$ & 0,351 \\
\hline 27. When a business gets big, it should be controlled by government. & 2,480 & 1,161 & 2,300 & 1,093 & 0,936 & 0,354 \\
\hline 28. New factories are not needed. & 4,310 & 1,130 & 4,460 & 0,905 & $-0,797$ & 0,429 \\
\hline
\end{tabular}

Table 4. Attitude scale factor structure related to economy course.

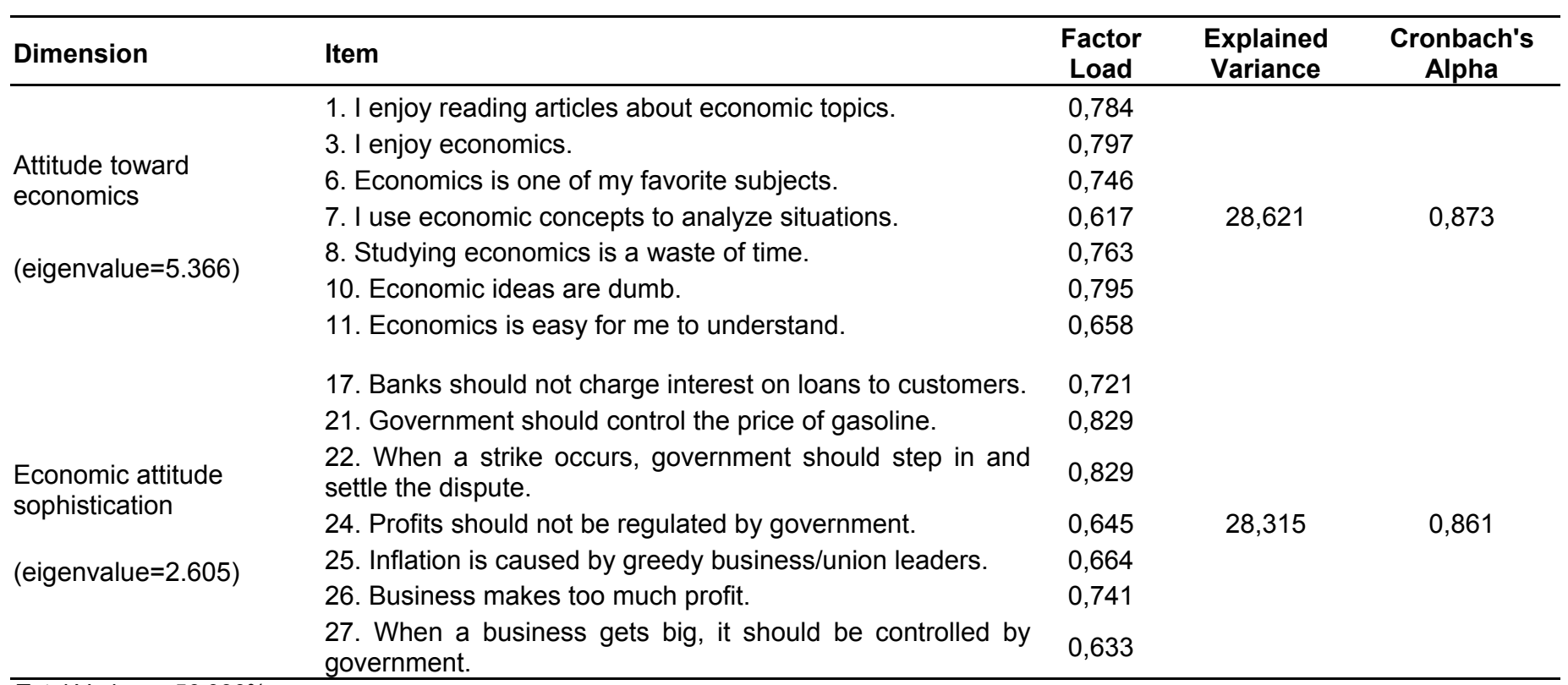


Table 5. The attitude scale towards economy course, factor loadings obtained via DFA and explained assumptions.

\begin{tabular}{|c|c|c|c|c|}
\hline Dimension & Item & $\begin{array}{l}\text { Factor } \\
\text { Load }\end{array}$ & $\begin{array}{l}\text { Explained } \\
\text { Variance }\end{array}$ & $\begin{array}{c}\text { Cronbach's } \\
\text { Alpha }\end{array}$ \\
\hline & 1. I enjoy reading articles about economic topics. & 0,784 & \multirow{7}{*}{28,621} & \multirow{7}{*}{0,873} \\
\hline Attitude toward & 3. I enjoy economics. & 0,797 & & \\
\hline economics & 6. Economics is one of my favorite subjects. & 0,746 & & \\
\hline \multirow{4}{*}{$\begin{array}{l}\text { (eigenvalue }=5.3 \\
66)\end{array}$} & 7. I use economic concepts to analyze situations. & 0,617 & & \\
\hline & 8. Studying economics is a waste of time. & 0,763 & & \\
\hline & 10. Economic ideas are dumb. & 0,795 & & \\
\hline & 11. Economics is easy for me to understand. & 0,658 & & \\
\hline \multirow{7}{*}{$\begin{array}{l}\text { Economic } \\
\text { attitude } \\
\text { sophistication } \\
\text { (eigenvalue=2.6 } \\
05 \text { ) }\end{array}$} & 17. Banks should not charge interest on loans to customers. & 0,721 & \multirow{7}{*}{28,315} & \multirow{7}{*}{0,861} \\
\hline & 21. Government should control the price of gasoline. & 0,829 & & \\
\hline & $\begin{array}{l}\text { 22. When a strike occurs, government should step in and settle the } \\
\text { dispute. }\end{array}$ & 0,829 & & \\
\hline & 24. Profits should not be regulated by government. & 0,645 & & \\
\hline & 25. Inflation is caused by greedy business/union leaders. & 0,664 & & \\
\hline & 26. Business makes too much profit. & 0,741 & & \\
\hline & 27. When a business gets big, it should be controlled by government. & 0,633 & & \\
\hline
\end{tabular}

Total variance $56.936 \%$.

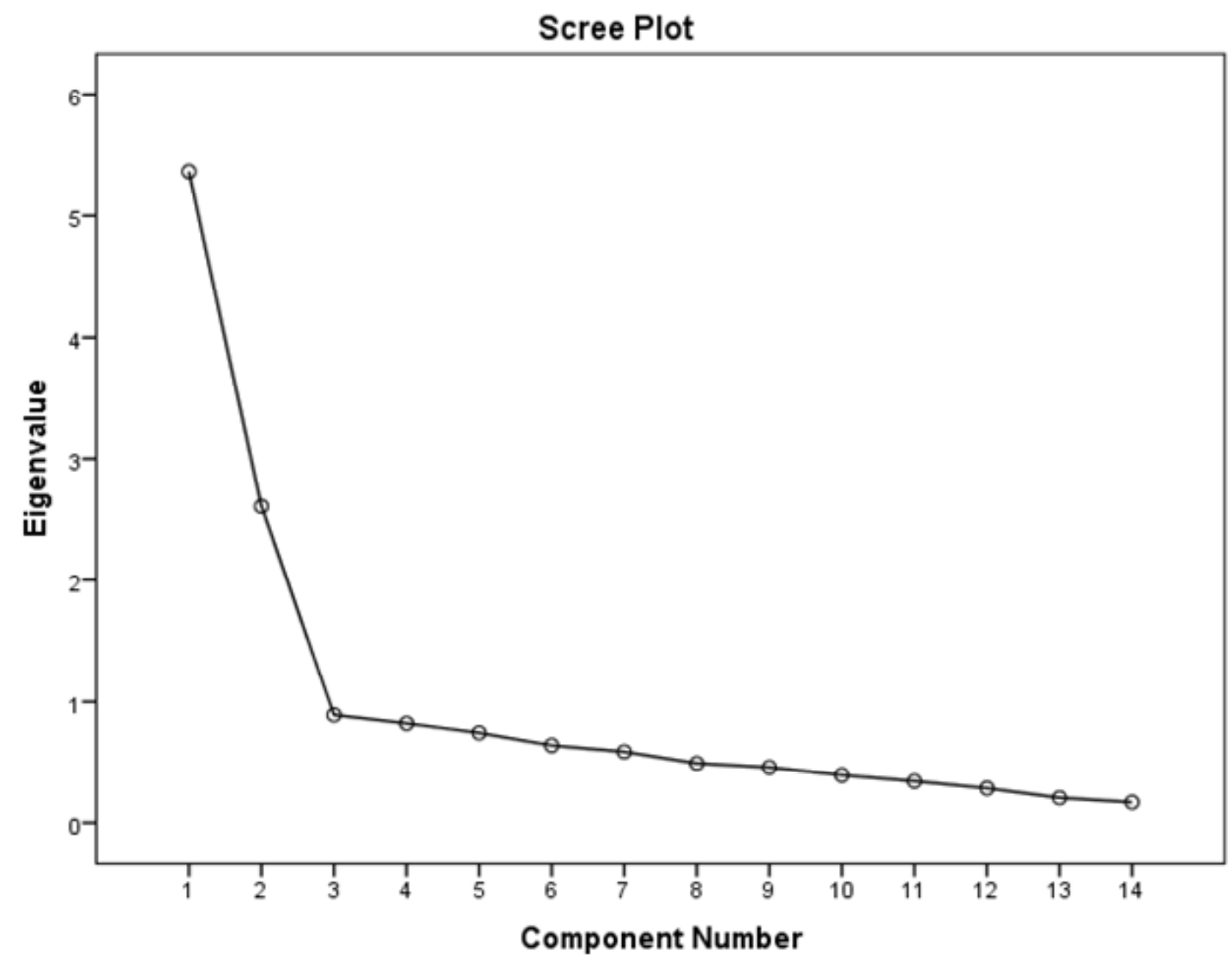

Figure 1. Scree plot test. 
Educ. Res. Rev.

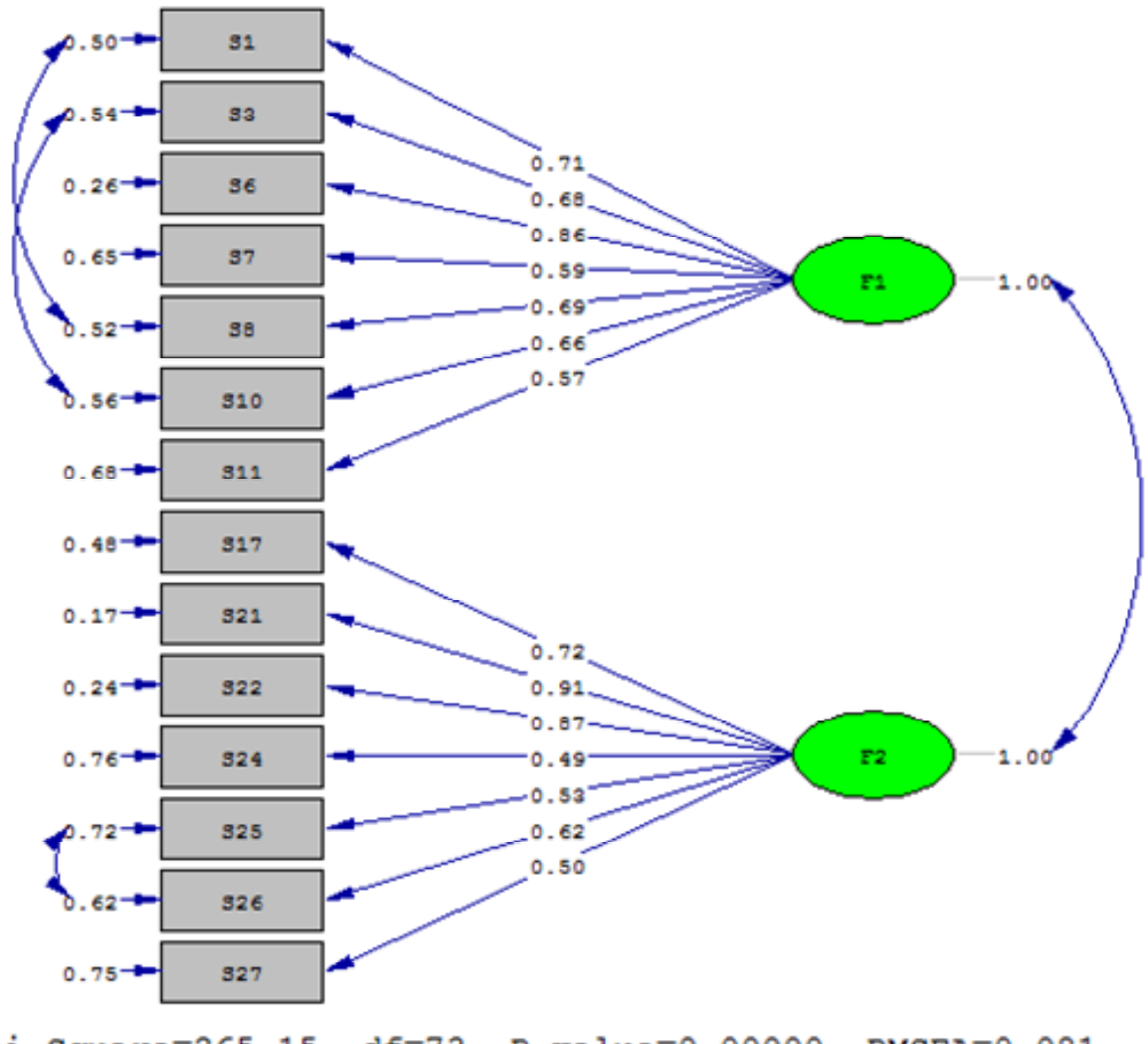

Chi-Square $=265.15, d f=73$, p-value $=0.00000$, RMSEA=0.081

Figure 2. Attitude scale related to economy course DFA factor loadings.

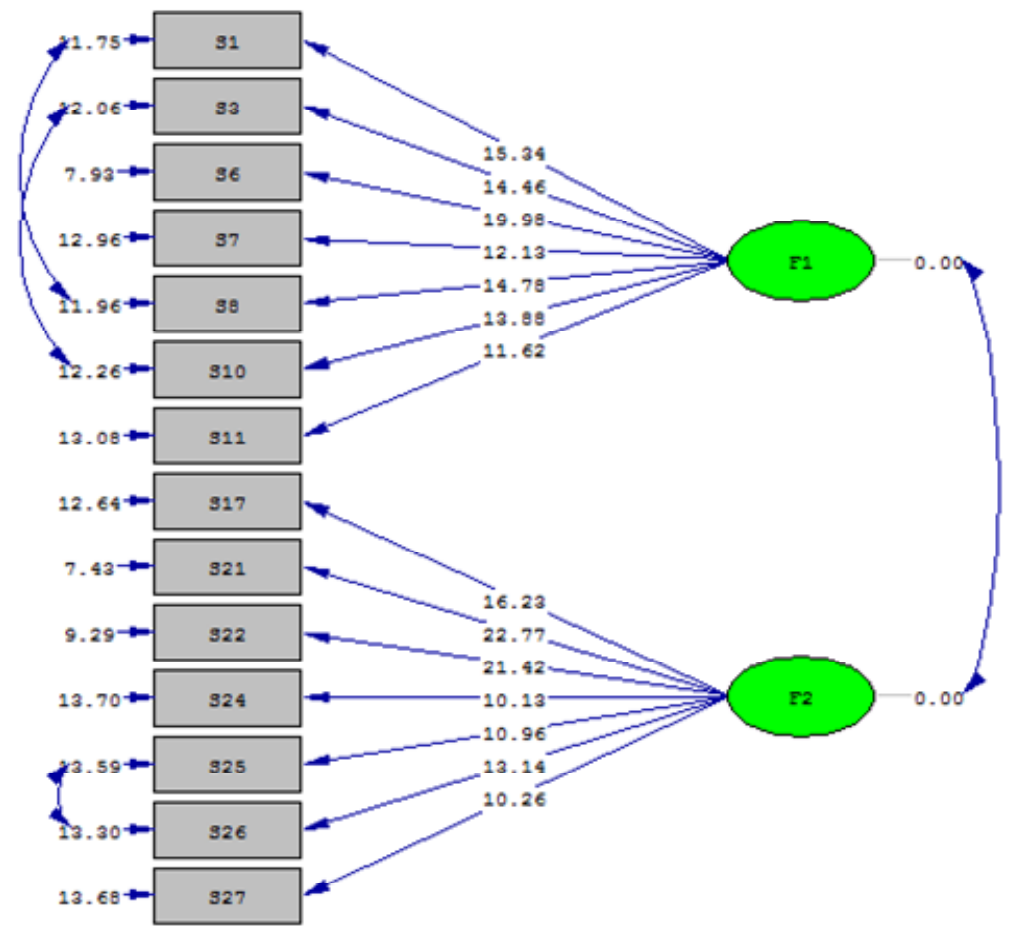

Chi-Square=265.15, df=73, p-value $=0.00000$, RMSEA=0.081

Figure 3. Attitude scale towards economy course DFA. $t$ test results are significant for all items $(t>1,96 ; p>0,05)$. 